\title{
PENGARUH LINGKUNGAN KERJA DAN DISIPLIN KERJA TERHADAP KINERJA KARYAWAN PADA PT MUSTIKA CITRA RASA
}

\author{
Liawati ${ }^{1}$, Widowati ${ }^{2}$ \\ Fakultas Ekonomi, Universitas Pamulang \\ Email: liaalea2@gmail.com ${ }^{1}$, widowati2808@gmail.com ${ }^{2}$
}

\begin{abstract}
Purpose. The purpose of this study was to determine and analyze the influence of the work environment and work discipline on employee performance at PT Mustika Citra Rasa.

Methods. This research is associative with a quantitative approach. The sample used in this study were 146 respondents. The data analysis technique used in this study is the validity test, reliability test, simple linear regression, correlation coefficient, determination coefficient, and t-test.

Findings. The results of the study are as follows: The work environment has a positive and significant effect on employee performance at PT Mustika Citra Rasa. This is evidenced by the tcount $10.415>t$ table 1.976 with a significant $0.000<0.05$. Simple linear regression equation $Y=22.154+0.284 X 1$. The contribution of the work environment to employee performance is $43 \%$. Work discipline has a positive and significant effect on employee performance at PT Mustika Citra Rasa. This is evidenced by the value of tcount 10.703> ttable 1.976 with a significant $0.000<0.05$. Simple linear regression equation: $Y=22.376+0.451 X 2$. The contribution of work discipline to employee performance is $44.3 \%$. Work environment and work discipline have a positive and significant effect on employee performance at PT Mustika Citra Rasa. This is evidenced by the value of Fcount 63.694> Ftable 3.91 with a significant level of $0.000<0.05$. Multiple linear regression equation $Y=20.930+0.139 X 1+0.265 X 2$. The magnitude of the influence of the work environment and work discipline simultaneously on employee performance is $46.4 \%$.
\end{abstract}

Implication. To increase employees' sense of responsibility, this can be done by giving full trust and support so that employees work creatively and innovatively and provide sanctions. Sanctions are needed to increase responsibility and educate employees to comply with all company regulations.

Keywords. Work Environment, Work Discipline and Employee Performance.

\begin{abstract}
ABSTRAK
Tujuan. Tujuan diadakannya penelitian ini adalah untuk mengetahui dan menganalisis Pengaruh Lingkungan Kerja dan Disiplin Kerja Terhadap Kinerja Karyawan Pada PT Mustika Citra Rasa.

Metode. Penelitian ini bersifat Asosiatif dengan pendekatan kuantitatif. Sampel yang digunakan dalam penelitian ini sebanyak 146 responden. Teknik analisis data yang digunakan dalam penelitian ini yaitu dengan uji validitas, uji reliabilitas, regresi linier sederhana, koefisien korelasi, koefisien determinasi, dan uji t hitung.

Hasil. Hasil penelitian sebagai berikut: Lingkungan kerja berpengaruh positif dan signifikan terhadap kinerja karyawan pada PT Mustika Citra Rasa hal tersebut dibuktikan darinilai $t_{\text {hitung }} 10,415>t_{\text {tabel }} 1,976$ dengan signifikan $0,000<0,05$. Persamaan regresi linier
\end{abstract}


sederhana $\mathrm{Y}=22,154+0,284 \mathrm{X}_{1}$. Besarnya kontribusi lingkungan kerja terhadap kinerja karyawan sebesar $43 \%$. Disiplin kerja berpengaruh positif dan signifikan terhadap kinerja karyawan pada PT Mustika Citra Rasa hal tersebut dibuktikan dari nilai thitung 10,703 $>t_{\text {tabel }}$ 1,976 dengan signifikan $0,000<0,05$. Persamaan regresi linier sederhana: $\mathrm{Y}=22,376+0,451 \mathrm{X}_{2}$. Besarnya kontribusi disiplin kerja terhadap kinerja karyawan sebesar 44,3\%. Lingkungan kerja dan disiplin kerja berpengaruh positif dan signifikan terhadap kinerja karyawan pada PT Mustika Citra Rasa hal tersebut dibuktikan dari nilai $\mathrm{F}_{\text {hitung }}$ 63,694 $>F_{\text {tabel }} 3,91$ dengan tingkat siginifikan 0,000 $<0,05$. Persamaan regresi linier berganda $Y=20,930+0,139 X_{1}+0,265 X_{2}$. Besarnya pengaruh lingkungan kerja dan disiplin kerjasecara simultan terhadap kinerja karyawan sebesar 46,4\%.

Implikasi. Untuk meningkatkan rasa tanggung jawab pegawai dapat dilakukan dengan cara memberikan kepercayaan dan dukungan sepenuhnya agar pegawai bekerja secara kreatif dan inovatif dan memberikan sanksi. Sanksi diperlukan dalam meningkatkan tanggung jawab dan mendidik pegawai supaya menaati semua peraturan perusahaan.

Kata Kunci. Lingkungan Kerja, Disiplin Kerja dan Kinerja Karyawan.

\section{Pendahuluan}

PT. Mustika Citra Rasa (Holland Bakery) adalah perusahaan roti premium terbesar dan juga dikenal untuk kualitas karena semua produk yang dibuat hanya dari bahan-bahan terbaik berkualitas tinggi, diproses dan dipanggang dengan kontrol kualitas yang ketat menggunakan mesin modern dan peralatan. Tidaklah mengherankan jika Holland Bakery memiliki motto: "Teratas Karena Kalitas dan Terbaik untuk kualitas". Holland Bakery memiliki lebih dari 200 outlet di Indonesia, dengan toko-toko yang berlokasi di Jakarta, Bandung, Surabaya, Lampung, Batam, Pekanbaru, Makassar, Manado, Solo, Bali, Balikpapan dan Semarang, karena ekspansi bisnis.

Adapun fenomena permasalahan terkait rendahnya kinerja karyawan di PT. Mustika Citra Rasa (Holland Bakery) berdasarkan pengamatan di lapangan, masih terjadi kesalahan komunikasi antar pegawai, contohnya pada saat karyawan dimintai laporan yang berkaitan dengan laporan keuangan, masih ada yang belum melaporkan sesuai dengan waktu yang ditentukan, sehingga terlihat bahwa kerjasama kurang terjalin antara satu pegawai dengan karyawan yang lain. Selain itu sikap karyawan yang kurang ramah terhadap pelanggan, dan pegawai kurang cepat dan cekatan dalam melayani permintaan pelanggan di toko.

Rendahnya kinerja karyawan dapat menyebabkan tujuan perusahaan tidak tercapai dengan baik karena terdapat tindakan karyawan yang tidak mendukung efektivitas dan efisiensi dalam melakukan pekerjaan. Akibatnya perusahaan harus menerima kerugian materil maupun immaterial karena pekerjaan karyawan yang selalu tidak tepat waktu. Pekerjaan yang tidak terselesaikan harus dikerjakan oleh karyawan lain, sehingga menyebabkan beban pekerjaan bertambah.

Menurut Mangkunegara (2015:125), faktor-faktor yang menyebabkan kinerja karyawan tinggi atau rendah dapat dipengaruhi oleh faktor disiplin kerja, kompensasi, kepemimpinan, komunikasi, kompetisi, motivasi, lingkungan kerja, pelatihan dan pendidikan. Semua faktorfaktor tersebut sangat berpengaruh antara karyawan perusahaan yang satu dengan karyawan perusahaan yang lainnya.

Lingkungan kerja memegang peranan penting terhadap baik buruknya kualitas hasil kinerja karyawan. Menurut Sedarmayanti (20016:21) "secara garis besar, jenis lingkungan kerja terbagi menjadi 2 yakni: 1) lingkungan kerja fisik, dan 2) lingkungan kerja non fisik". Sedarmayanti (2016:31) menyatakan bahwa "lingkungan kerja non fisik adalah semua keadaan yang terjadi yang berkaitan dengan hubungan kerja, baik dengan atasan maupun dengan sesama rekan kerja ataupun hubungan dengan bawahan". Bila lingkungan kerja nyaman dan komunikasi antar karyawan berjalan lancar, maka bisa dipastikan performa yang dihasilkan pun akan maksimal. 
Faktor selanjutnya yang mempengarui kinerja pegawai adalah disiplin kerja. Menurut Sinungan (2014:135), Disiplin adalah sikap kejiwaan dari seseorang atau sekelompok orang yang senatiasa berkehendak untuk mengikuti/mematuhi segala aturan/keputusan yang telah ditetapkan". Disiplin dalam hubungan kerja sangat erat kaitannya dengan motivasi kerja. Disiplin dapat dikembangkan melalui suatu latihan antara lain dengan berkerja dengan menghargai waktu, tenaga dan biaya.

Permasalahan yang terjadi pada PT Mustika Citra Rasa terkait dengan kedisiplinan yang rendah yaitu ketaatan karyawan dalam aturan waktu masih rendah seperti masih ada karyawan yang datang terlambat ketempat kerja, karyawan sering libur diluar hari libur yang telah ditetapkan perusahaan (karyawan membolos) dan tidak minta izin untuk meninggalkan pekerjaan. Selain itu telat masuk setelah istirahat, serta pulang lebih cepat sebelum waktunya, masih adanya karyawan yang mengobrol diruangan kerja sedangkan karyawan yang lain sibuk menyelesaikan pekerjaannya.

Berdasarkan latar belakang masalah yang telah diuraikan diatas maka penulis merasa tertarik dengan mengambil judul, Pengaruh Lingkungan Kerja dan Disiplin Kerja Terhadap Kinerja Karyawan Pada PT Mustika Citra Rasa.

\section{Kajian Pustaka dan Hipotesis}

Lingkungan Kerja. Siagian (2014:56) mengemukakan bahwa "lingkungan kerja adalah lingkungan dimana pegawai melakukan pekerjaannya sehari-hari". Sedarmayanti (2016:23) mengemukakan bahwa "lingkungan kerja adalah suatu tempat yang terdapat sebuah kelompok dimana di dalamnya terdapat beberapa fasilitas pendukung untuk mencapai tujuan perusahaan sesuai dengan visi dan misi perusahaan". Menurut Nuraini (2013:97), "Lingkungan kerja adalah segala sesuatu yang ada disekitar karyawan dan dapat mempengaruhi dalam menjalankan tugas yang diembankan kepadanya misalnya dengan adanya air conditioner (AC), penerangan yang memadai dan sebagainya".

Disiplin Kerja. Menurut Hasibuan (2016:193), "kedisiplinan adalah kesadaran dan kesediaan seseorang menaati semua peraturan perusahaan dan norma-norma sosial yang berlaku". Menurut Mangkunegara (2015:129) "Kedisiplinan dapat diartikan sebagai pelaksanaan manajemen untuk memperteguh pedoman-pedoman organisasi". Menurut Sutrisno (2016:87) bahwa "disiplin mempunyai dua pengertian. Arti yang pertama, melibatkan belajar atau mencetak perilaku dengan menerapkan imbalan atau hukuman. Arti kedua, lebih sempit lagi, yaitu disiplin ini hanya bertalian dengan tindakan hukuman terhadap perilaku kesalahan".

Kinerja Karyawan. Istilah kinerja berasal dari kata job perfomance atau actual perfomance (prestasi kerja atau prestasi sesungguhnya yang dicapai oleh seseorang). Menurut Robert dan Bacal (2016:153) "kinerja merupakan tingkat kontribusi yang diberikan pegawai terhadap tujuan pekerjaannya atau unit kerja dan perusahaan/organisasi sebagai hasilperilakunya dan aplikasi dari keterampilan, kemampuan, dan pengetahuannya". Rivai dan Sagala (2016:269270) menyatakan bahwa "kinerja adalah perilaku yang nyata yang ditampilkan setiap orang sebagai prestasi kerja yang dihasilkan oleh pegawai sesuai dengan perannya dalam organisasi". "Performance is ouput derives from processes, human otherwise," yang artinya Kinerja merupakan hasil dari suatu proses yang dilakukan manusia (Priansah, 2016:196).

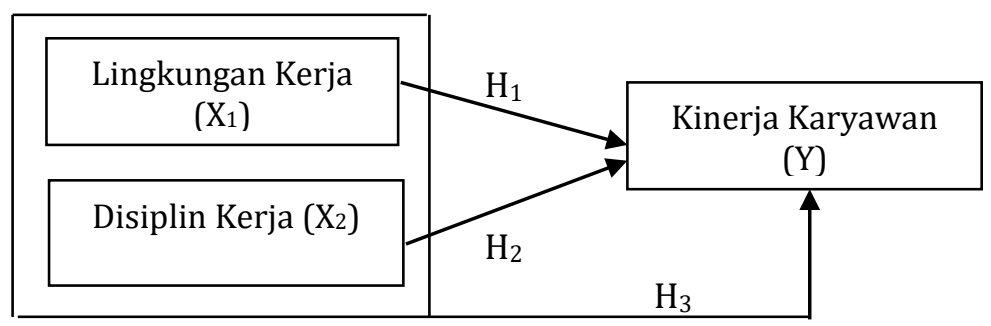

Gambar 1. Model Penelitian 


\section{Hipotesis}

H1 : Terdapat pengaruh positif dan signifikan lingkungan kerja terhadap kinerja karyawan PT Mustika Citra Rasa.

H2 : Terdapat pengaruh positif dan signifikan disiplin kerja terhadap kinerja karyawan PT Mustika Citra Rasa.

H3 : Terdapat pengaruh positif dan signifikan lingkungan kerja dan disiplin kerja secara simultan terhadap kinerja karyawan PT Mustika Citra Rasa.

\section{Metode Penelitian}

Jenis penelitian ini adalah asosiatif, menurut Sugiyono (2017:44) yaitu "Penelitian yang bertujuan untuk mengetahui pengaruh atau hubungan antara dua variabel atau lebih". Dengan demikian penelitian asosiatif ini dapat dibangun suatu teori yang berfungsi untuk menjelaskan, meramalkan dan mengontrol suatu gejala. Populasi dari penelitian ini adalah seluruh karyawan pada PT Mustika Citra Rasa berjumlah 230 orang. Adapun jumlah sampel yang digunakan sebanyak 146 responden.

\section{Uji Instrumen Penelitian}

Dalam suatu penelitian, data mempunyai kedudukan yang sangat penting. Hal ini dikarenakan data merupakan penggambaran variabel yang diteliti dan berfungsi sebagai alat pembuktian hipotesis. Valid atau tidaknya data sangat menentukan kualitas dari data tersebut. Hal ini tergantung instrumen yang digunakan apakah sudah memenuhi asas validitas dan reliabilitas. Adapun dalam pengujian instrumen ini digunakan 2 (dua) pengujian yaitu validitas dan reliabilitas.

\section{Uji Asumsi Klasik}

Uji asumsi klasik digunakan untuk mengetahui ketepatan sebuah data. Menurut Santoso (2015:342) berpendapat "Sebuah model regresi akan digunakan untuk melakukan peramalan sebuah model yang baik adalah model dengan kesalahan peramalan yang seminimal mungkin. Karena itu, sebuah model sebelum digunakan seharusnya memenuhi beberapa asumsi, yang biasa disebut asumsi klasik". Dalam penelitian ini uji asumsi klasik yang digunakan: Uji Normalitas, Uji Multikolinearitas, Uji Autokorelasi, dan Uji Heterokedastisitas.

\section{Analisis Kuantitatif}

Analisis kuantitatif adalah penelitian untuk menilai kondisi dari nilai pengaruh, dan signifikansi pengaruh tersebut. Dalam penelitian ini analisis kuantitatif yang digunakan: Analisis Regresi Linier Sederhana, Linier Berganda, Analisis Koefisien Korelasi, Analisis Koefisien Determinasi, Pengujian Hipotesis.

\section{Hasil Penelitian dan Pembahasan Uji Validitas Instrumen}

Tabel 1. Hasil Uji Validitas Variabel Lingkungan Kerja $\left(\mathrm{X}_{1}\right)$

\begin{tabular}{|c|c|c|c|}
\hline Pernyataan & Nilai $\mathbf{r}_{\text {hitung }}$ & Nilai $\mathbf{r}_{\text {tabel }}$ & Keterangan \\
\hline Pernyataan 1 & 0,584 & 0,162 & Valid \\
\hline Pernyataan 2 & 0,628 & 0,162 & Valid \\
\hline Pernyataan 3 & 0,694 & 0,162 & Valid \\
\hline Pernyataan 4 & 0,783 & 0,162 & Valid \\
\hline Pernyataan 5 & 0,873 & 0,162 & Valid \\
\hline Pernyataan 6 & 0,947 & 0,162 & Valid \\
\hline Pernyataan 7 & 0,904 & 0,162 & Valid \\
\hline Pernyataan 8 & 0,718 & 0,162 & Valid \\
\hline Pernyataan 9 & 0,860 & 0,162 & Valid \\
\hline
\end{tabular}




\begin{tabular}{|c|c|c|c|}
\hline Pernyataan & Nilai $\mathbf{r}_{\text {hitung }}$ & Nilai $\mathbf{r}_{\text {tabel }}$ & Keterangan \\
\hline Pernyataan 10 & 0,902 & 0,162 & Valid \\
\hline Pernyataan 11 & 0,908 & 0,162 & Valid \\
\hline Pernyataan 12 & 0,867 & 0,162 & Valid \\
\hline Pernyataan 13 & 0,861 & 0,162 & Valid \\
\hline Pernyataan 14 & 0,885 & 0,162 & Valid \\
\hline Pernyataan 15 & 0,904 & 0,162 & Valid \\
\hline Pernyataan 16 & 0,821 & 0,162 & Valid \\
\hline
\end{tabular}

Sumber : Data diolah (2021)

Tabel 2. Hasil Uji Validitas Variabel Disiplin Kerja $\left(\mathrm{X}_{2}\right)$

\begin{tabular}{|c|c|c|c|}
\hline Pernyataan & Nilai $\mathbf{r}_{\text {hitung }}$ & Nilai $\mathbf{r}_{\text {tabel }}$ & Keterangan \\
\hline Pernyataan 1 & 0,745 & 0,162 & Valid \\
\hline Pernyataan 2 & 0,780 & 0,162 & Valid \\
\hline Pernyataan 3 & 0,814 & 0,162 & Valid \\
\hline Pernyataan 4 & 0,888 & 0,162 & Valid \\
\hline Pernyataan 5 & 0,881 & 0,162 & Valid \\
\hline Pernyataan 6 & 0,909 & 0,162 & Valid \\
\hline Pernyataan 7 & 0,905 & 0,162 & Valid \\
\hline Pernyataan 8 & 0,810 & 0,162 & Valid \\
\hline Pernyataan 9 & 0,868 & 0,162 & Valid \\
\hline Pernyataan 10 & 0,860 & 0,162 & Valid \\
\hline
\end{tabular}

Sumber : Data diolah (2021)

Tabel 3. Hasil Uji Validitas Variabel Kinerja Karyawan (Y)

\begin{tabular}{|c|c|c|c|}
\hline Pernyataan & Nilai $\mathbf{r}_{\text {hitung }}$ & Nilai $\mathbf{r}_{\text {tabel }}$ & Keterangan \\
\hline Pernyataan 1 & 0,865 & 0,162 & Valid \\
\hline Pernyataan 2 & 0,853 & 0,162 & Valid \\
\hline Pernyataan 3 & 0,934 & 0,162 & Valid \\
\hline Pernyataan 4 & 0,793 & 0,162 & Valid \\
\hline Pernyataan 5 & 0,808 & 0,162 & Valid \\
\hline Pernyataan 6 & 0,492 & 0,162 & Valid \\
\hline Pernyataan 7 & 0,758 & 0,162 & Valid \\
\hline Pernyataan 8 & 0,576 & 0,162 & Valid \\
\hline Pernyataan 9 & 0,913 & 0,162 & Valid \\
\hline Pernyataan 10 & 0,808 & 0,162 & Valid \\
\hline
\end{tabular}

Sumber : Data diolah (2021)

Berdasarkan data tabel di atas, variabel $\mathrm{X}_{1}, \mathrm{X}_{2}$ dan $\mathrm{Y}$ diperoleh nilai $\mathrm{r}$ hitung $>\mathrm{r}$ tabel (0.162), dengan demikian maka semua item kuesioner dinyatakan valid. Untuk itu kuesioner yang digunakan layak untuk diolah sebagai data penelitian.

\section{Uji Reliabilitas Instrumen}

Tabel 4. Hasil Uji Reliabilitas Variabel Independen dan Dependen

\begin{tabular}{|c|c|c|c|}
\hline Variabel & Cronbatch Alpha & Standar Cronbatch Alpha & Keputusan \\
\hline Disiplin Kerja (X1) & 0,967 & 0,60 & Reliabel \\
\hline Lingkungan Kerja (X2) & 0,955 & 0,60 & Reliabel \\
\hline Kinerja Karyawan (Y) & 0,929 & 0,60 & Reliabel \\
\hline
\end{tabular}

Sumber : Data diolah (2021)

Berdasarkan tabel 4 tersebut dapat diketahui bahwa masing-masing variabel lingkungan kerja, disiplin kerja, dan kinerja karyawan, memiliki nilai Cronbach Alpha $>0,60$. Dengan demikian maka hasil uji reliabilitas terhadap keseluruhan variabel adalah sangat reliabel, 
sehingga semua butir pertanyaan dapat dipercaya dan dapat digunakan untuk penelitian selanjutnya.

\section{Pengujian Asumsi Klasik (Uji Prasyarat Data)}

\section{Uji Normalitas}

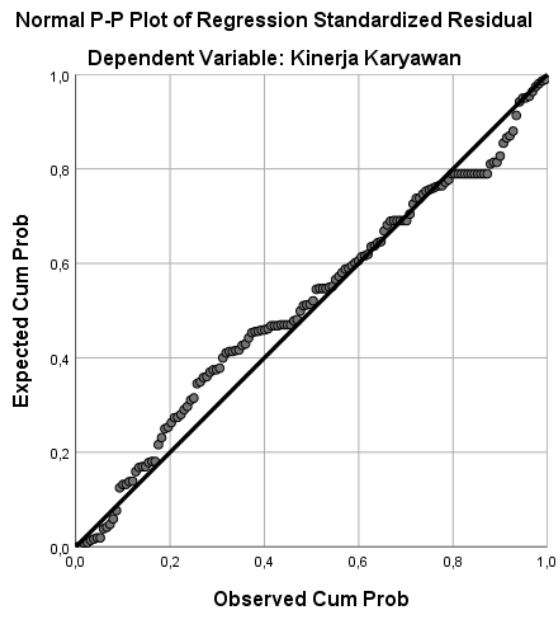

Gambar 2. Hasil Uji Normalitas

Sumber : Data diolah (2021)

Melihat tampilan grafik normal probability plot di atas, dapat disimpulkan bahwa pada grafik normal probability plot terlihat titik-titik menyebar di sekitar garis diagonal dan penyebarannya mengikuti arah garis diagonal, sehingga dapat disimpulkan bahwa data yang digunakan dalam penelitian ini berdistribusi normal.

\section{Uji Multikolinearitas}

Tabel 5. Hasil Pengujian Multikolinearitas

\begin{tabular}{|c|c|c|}
\hline \multirow{2}{*}{ Variabel } & \multicolumn{2}{|c|}{ Colinerity Statistics } \\
\cline { 2 - 3 } & Tolerance & VIF \\
\hline Lingkungan Kerja & 0,271 & 3,686 \\
\hline Disiplin Kerja & 0,271 & 3,686 \\
\hline
\end{tabular}

Sumber : data output yang diolah, (2021)

Berdasarkan tabel tersebut maka dapat diketahui nilai tolerance variabel lingkungan kerja dan disiplin kerja sebesar 0,271 $>0,10$ dan nilai VIF variabel lingkungan kerja dan disiplin kerja sebesar 3,686 < 10, sehingga dapat disimpulkan bahwa variabel disiplin kerja dan pelatihan kerja tidak terjadi gejala multikolinieritas.

\section{Uji Heteroskedastisitas}




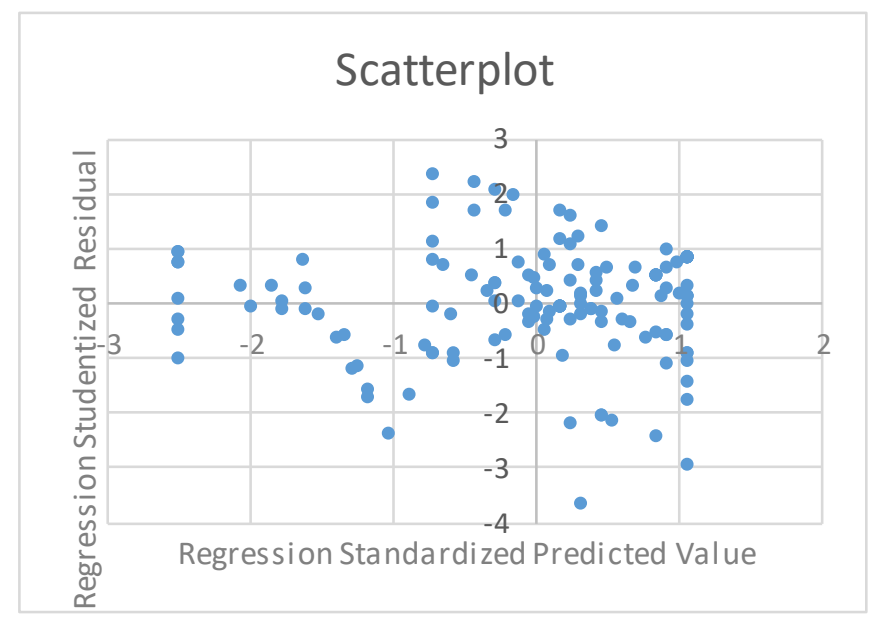

Sumber : data output yang diolah, (2021)

\section{Gambar 1 Uji Heteroskedastisitas}

Dari grafik tersebut, dapat terlihat titik-titik yang menyebar secara acak, tidak membentuk suatu pola tertentu yang jelas, serta tersebar baik di atas maupun di bawah angka 0 (nol) pada sumbu Y, maka tidak terjadi heteroskedastisitas.

\section{Analisis Kuantitatif}

\section{Regresi Linier Berganda}

Tabel 6. Hasil Pengujian Regresi Berganda

\begin{tabular}{|c|c|c|c|c|c|c|}
\hline \multirow{2}{*}{\multicolumn{2}{|c|}{ Model }} & \multicolumn{2}{|c|}{$\begin{array}{l}\text { Unstandardized } \\
\text { Coefficients }\end{array}$} & \multirow{2}{*}{$\begin{array}{c}\begin{array}{c}\text { Standardized } \\
\text { Coefficients }\end{array} \\
\text { Beta }\end{array}$} & \multirow[t]{2}{*}{$\mathrm{t}$} & \multirow[t]{2}{*}{ Sig. } \\
\hline & & B & Std. Error & & & \\
\hline \multirow[t]{3}{*}{1} & (Constant) & 20,930 & 1,717 & & 12,192 & 0,000 \\
\hline & Lingkungan Kerja & 0,139 & 0,051 & 0,322 & 2,755 & 0,007 \\
\hline & Disiplin Kerja & 0,265 & 0,079 & 0,391 & 3,349 & 0,001 \\
\hline
\end{tabular}

a. Dependent Variable: Kinerja Karyawan

Sumber : Data diolah (2021)

Berdasarkan hasil perhitungan tersebut maka dapat diperoleh persamaan regresi linier

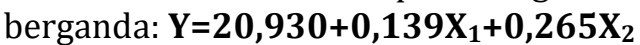

a. Nilai konstanta sebesar 20,930 nilai ini menunjukan bahwa pada saat lingkungan kerja dan disiplin kerja, bernilai nol atau tidak meningkat, maka kinerja karyawan akan tetap bernilai 20,930 .

b. Nilai regresi $0,139 \mathrm{X}_{1}$ artinya apabila variabel lingkungan kerja $\left(\mathrm{X}_{1}\right)$ meningkat sebesar 1 satuan dengan asumsi variabel disiplin kerja $\left(\mathrm{X}_{2}\right)$ tetap, maka kinerja karyawan $(\mathrm{Y})$ akan meningkat sebesar 0,139 satuan.

c. Nilai regresi $0,265 \mathrm{X}_{2}$ artinya apabila variabel disiplin kerja $\left(\mathrm{X}_{2}\right)$ meningkat sebesar 1 satuan dengan asumsi variabel lingkungan kerja $\left(\mathrm{X}_{1}\right)$ tetap, maka kinerja karyawan $(\mathrm{Y})$ akan meningkat sebesar 0,265 satuan.

\section{Hasil Koefisien Determinasi}

Tabel 7. Koefisien Determinasi $\left(\mathrm{X}_{1}\right)$ Terhadap (Y)

\begin{tabular}{|c|c|c|c|c|}
\hline Model & $\mathrm{R}$ & $\mathrm{R}$ Square & $\begin{array}{c}\text { Adjusted R } \\
\text { Square }\end{array}$ & $\begin{array}{c}\text { Std. Error of } \\
\text { the Estimate }\end{array}$ \\
\hline 1 &, $655^{\mathrm{a}}$ & 0,430 & 0,426 & 6,02408 \\
\hline
\end{tabular}

a. Predictors: (Constant), Lingkungan Kerja

Sumber : Data diolah (2021) 
Berdasarkan Tabel tersebut maka dapat diketahui bahwa besarnya nilai koefisien determinasi ditunjukkan oleh nilai $R$ Square sebesar 0,430 yang artinya variabel lingkungan kerja $\left(\mathrm{X}_{1}\right)$ memberikan kontribusi terhadap variabel kinerja karyawan (Y) sebesar $43 \%$, sedangkan sisanya sebesar $57 \%$ di pengaruhi oleh variabel lain yang tidak diteliti dalam penelitian ini.

Tabel 8. Koefisien Determinasi $\left(\mathrm{X}_{2}\right)$ Terhadap ( $\left.\mathrm{Y}\right)$

\begin{tabular}{|c|c|c|c|c|}
\hline Model & $\mathrm{R}$ & R Square & Adjusted R Square & $\begin{array}{c}\text { Std. Error of the } \\
\text { Estimate }\end{array}$ \\
\hline 1 &, $666^{\mathrm{a}}$ & 0,443 & 0,439 & 5,95291 \\
\hline
\end{tabular}

a. Predictors: (Constant), Disiplin Kerja

Sumber : Data diolah (2021)

Berdasarkan Tabel diatas, maka dapat diketahui bahwa besarnya nilai koefisien determinasi ditunjukkan oleh nilai $R$ Square sebesar 0,443 yang artinya variabel disiplin kerja $\left(\mathrm{X}_{2}\right)$ memberikan kontribusi terhadap variabel kinerja karyawan $(\mathrm{Y})$ sebesar 44,3\%, sedangkan sisanya sebesar $54,7 \%$ di pengaruhi oleh variabel lain yang tidak diteliti dalam penelitian ini.

Tabel 9. Koefisien Determinasi $\left(X_{1}\right)$ dan $\left(X_{2}\right)$ Terhadap $(Y)$

\begin{tabular}{|c|c|c|c|c|}
\hline Model & $\mathrm{R}$ & R Square & $\begin{array}{c}\text { Adjusted R } \\
\text { Square }\end{array}$ & $\begin{array}{c}\text { Std. Error of the } \\
\text { Estimate }\end{array}$ \\
\hline 1 &, $686^{\mathrm{a}}$ & 0,471 & 0,464 & 5,82118 \\
\hline
\end{tabular}

a. Predictors: (Constant), Disiplin Kerja, Lingkungan Kerja

Sumber : Data diolah (2021)

Berdasarkan Tabel diatas, maka dapat diketahui bahwa besarnya nilai koefisien determinasi ditunjukkan oleh nilai Adjusted $R$ Square sebesar 0,464 artinya variabel lingkungan kerja $\left(\mathrm{X}_{1}\right)$ dan disiplin kerja $\left(\mathrm{X}_{2}\right)$ memberikan kontribusi terhadap variabel kinerja karyawan (Y) sebesar 46,4\%, sedangkan sisanya sebesar 53,6\% di pengaruhi oleh variabel lain yang tidak diteliti dalam penelitian ini.

\section{Uji Hipotesis}

Tabel 10. Uji $t_{\text {hitung }}\left(X_{1}\right)$ Terhadap ( $\left.Y\right)$

\begin{tabular}{|l|l|r|r|r|r|r|}
\hline \multicolumn{2}{|c|}{ Model } & \multicolumn{2}{|c|}{$\begin{array}{c}\text { Unstandardized } \\
\text { Coefficients }\end{array}$} & $\begin{array}{c}\text { Standardized } \\
\text { Coefficients }\end{array}$ & \multirow{2}{*}{ t } & \multirow{2}{*}{ Sig. } \\
\cline { 3 - 5 } \multicolumn{2}{|c|}{} & \multicolumn{1}{|c|}{ B } & Std. Error & Beta & & \\
\hline \multirow{2}{*}{1} & (Constant) & 22,154 & 1,736 & & 12,762 & 0,000 \\
\cline { 2 - 6 } & Lingkungan Kerja & 0,284 & 0,027 & 0,655 & 10,415 & 0,000 \\
\hline
\end{tabular}

a. Dependent Variable: Kinerja Karyawan

Sumber : Data diolah (2021)

Berdasarkan pada Tabel tersebut dapat diketahui bahwa nilai thitung 10,415 $>t_{\text {tabel }}$ 1,976 dengan signifikan 0,000 $<0,05$ maka H0 ditolak dan Ha diterima menandakan bahwa terdapat pengaruh positif dan signifikan lingkungan kerja terhadap kinerja karyawan.

Tabel 11. Uji thitung $\left(\mathrm{X}_{2}\right)$ Terhadap ( $\left.\mathrm{Y}\right)$

\begin{tabular}{|c|l|r|r|r|r|c|}
\hline \multirow{2}{*}{\multicolumn{2}{|c|}{ Model }} & \multicolumn{2}{|c|}{$\begin{array}{c}\text { Unstandardized } \\
\text { Coefficients }\end{array}$} & $\begin{array}{c}\text { Standardized } \\
\text { Coefficients }\end{array}$ & \multirow{2}{*}{$\mathrm{t}$} & \multirow{2}{*}{ Sig. } \\
\cline { 3 - 5 } & \multicolumn{1}{|c|}{ B } & Std. Error & Beta & & \\
\hline \multirow{2}{*}{1} & (Constant) & 22,376 & 1,672 & & 13,386 & 0,000 \\
\cline { 2 - 6 } & Disiplin Kerja & 0,451 & 0,042 & 0,666 & 10,703 & 0,000 \\
\hline
\end{tabular}

a. Dependent Variable: Kinerja Karyawan

Sumber : Data diolah (2021) 
Berdasarkan pada Tabel tersebut dapat diketahui bahwa nilai $t_{\text {hitung }} 10,703>t_{\text {tabel }}$ 1,976 dengan signifikan 0,000 $<0,05$ maka H0 ditolak dan Ha diterima menandakan bahwa terdapat pengaruh positif dan signifikan disiplin kerja terhadap kinerja karyawan.

Tabel 12. Uji Fhitung

\begin{tabular}{|c|l|r|r|r|r|c|}
\hline \multicolumn{2}{|c|}{ Model } & $\begin{array}{c}\text { Sum of } \\
\text { Squares }\end{array}$ & \multicolumn{1}{c|}{ df } & $\begin{array}{c}\text { Mean } \\
\text { Square }\end{array}$ & F & \multicolumn{1}{c|}{ Sig. } \\
\hline \multirow{2}{*}{1} & Regression & 4316,673 & 2 & 2158,337 & 63,694 &, $000^{\text {b }}$ \\
\cline { 2 - 7 } & Residual & 4845,717 & 143 & 33,886 & & \\
\cline { 2 - 8 } & Total & 9162,390 & 145 & & & \\
\hline
\end{tabular}

a. Dependent Variable: Kinerja Karyawan

b. Predictors: (Constant), Disiplin Kerja, Lingkungan Kerja

Sumber : Data diolah (2021)

Berdasarkan tabel tersebut diperoleh nilai $\mathrm{F}_{\text {hitung }} 63,694>\mathrm{F}_{\text {tabel }}$ 3,91 dengan tingkat siginifikan $0,000<0,05$ dengan demikian Ho ditolak dan Ha diterima, artinya secara simultan terdapat pengaruh positif dan signifikan lingkungan kerja dan disiplin kerja terhadap kinerja karyawan.

\section{Kesimpulan}

Berdasarkan hasil penelitian pada PT Mustika Citra Rasa, maka dapat diambil kesimpulan sebagai berikut: Lingkungan kerja berpengaruh positif dan signifikan terhadap kinerja karyawan pada PT Mustika Citra Rasa hal tersebut dibuktikan darinilai $t_{\text {hitung }} 10,415>$ $t_{\text {tabel }} 1,976$ dengan signifikan $0,000<0,05$. Persamaan regresi linier sederhana $\mathrm{Y}=22,154+0,284 \mathrm{X}_{1}$. Besarnya kontribusi lingkungan kerja terhadap kinerja karyawan sebesar 43\%. Disiplin kerja berpengaruh positif dan signifikan terhadap kinerja karyawan pada PT Mustika Citra Rasa hal tersebut dibuktikan dari nilai $t_{\text {hitung }} 10,703>t_{\text {tabel }} 1,976$ dengan signifikan $0,000<0,05$. Persamaan regresi linier sederhana: $\mathrm{Y}=22,376+0,451 \mathrm{X}_{2}$. Besarnya kontribusi disiplin kerja terhadap kinerja karyawan sebesar 44,3\%. Lingkungan kerja dan disiplin kerja berpengaruh positif dan signifikan terhadap kinerja karyawan pada PT Mustika Citra Rasa hal tersebut dibuktikan dari nilai $F_{\text {hitung }} 63,694>F_{\text {tabel }}$ 3,91 dengan tingkat siginifikan $0,000<0,05$. Persamaan regresi linier berganda $Y=20,930+0,139 X_{1}+0,265 X_{2}$. Besarnya pengaruh lingkungan kerja dan disiplin kerjasecara simultan terhadap kinerja karyawan sebesar $46,4 \%$.

\section{Daftar Pustaka}

Andriani, J., Sularmi, L., \& Anggraini, N. (2021). Pengaruh Lingkungan Kerja Dan Motivasi Terhadap Kinerja Karyawan Pada PT. Naga Mas Intipratama Tangerang. Jurnal Arastirma, 1(1), 43-54. Https://Doi.Org/10.32493/Arastirma.V1i1.10061

Darmadi, D., Suryani, N. L., \& Sari, R. (2021). Pengaruh Budaya Organisasi Dan Disiplin Kerja Terhadap Kinerja Karyawan Di Divisi Likuid Pada PT. Eagle Indo Pharma-Tangerang. Jurnal Arastirma, 1(1), 56-57. Https://Doi.Org/10.32493/Arastirma.V1i1.10062

Hasibuan, Malayu, (2016), Manajemen Sumber Daya Manusia. Edisi Revisi. Jakarta: Penerbit PT Bumi Aksara.

Mangkunegara. A.P. (2015). Manajemen Sumber Daya Manusia Perusahaan, Bandung: PT. Remaja Rosdakarya.

Noviyanti, I., \& Ramadan, A. S. (2021). Pengaruh Kedisiplinan Dan Kompensasi Terhadap Kinerja Karyawan Pada PT. Mitra Pinanthika Mustika Rent Di Tangerang. Jurnal Arastirma, 1(1), 22-32. Https://Doi.Org/10.32493/Arastirma.V1i1.10039

Nuraini, T. (2013). Manajemen Sumber Daya Manusia, Pekanbaru: Yayasan Aini Syam. 
Priansa. D.J. (2016). Manajemen SDM dalam Organisasi Publik dan Bisnis. Bandung: Alfabeta.

Rivai, Veithzal, (2015), Manajemen Sumber Daya Manusia untuk Perusahaan, Edisi ke 6, Depok: PT. Raja Grafindo Persada.

Robert \& Bacal. (2016). Performance Management. Jakarta: GPU.

Santoso, S. (2015). SPSS20 Pengolahan Data Statistik di Era Informasi, Jakarta, PT. Alex Media Komputindo, Kelompok Gramedia.

Sedarmayanti. (2016). Tata Keraja dan Produktifitas Keraja. Bandung: Mandar Maju.

Siagian, Sondang. P. (2014). Manajemen Sumber Daya Manusia. Jakarta: Bumi Aksara.

Sugiyono, (2017), Metode Penelitian Manajemen, Bandung: CV Alvabeta.

Sutrisno, E. (2016). Manajemen Sumber Daya Manusia. Cetakan ke-8. Jakarta: Prenada Media Group. 